\title{
Northern Shrimp (Pandalus borealis) Recruitment in West Greenland Waters Part II. Lipid Classes and Fatty Acids in Pandalus Shrimp Larvae: Implications for Survival Expectations and Trophic Relationships
}

\author{
S. A. Pedersen and L. Storm \\ Greenland Institute of Natural Resources/Danish Institute for Fisheries Research \\ Department of Marine Ecology and Aquaculture \\ Kavalergården 6, DK-2920 Charlottenlund, Denmark
}

\begin{abstract}
Lipid class and fatty acid compositions were determined in shrimp larvae (Pandalus borealis and P. montagui) collected along transects across banks on the West Greenland shelf in June 1999, May and July 2000. The lipid class contents were investigated as indices of larval shrimp lipid condition and food type. Fatty acid compositions were investigated for lipid biomarkers to establish trophic relationships between larval shrimp and potential prey.

Phospholipids were the dominant lipid class in all six pelagic development stages of larval P. borealis and P. montagui, accounting for 80 to $92 \%$ of the total lipid.

In all six stages the contents of free fatty acids were more abundant than triacylglycerol. With increasing larval size from hatching to a carapace length of $\sim 2.3 \mathrm{~mm}$, there was a decreasing trend in the contents of hydrocarbons attributed to reduced amount of phytoplankton in the diet. Triacylglycerol (TG) content to wet weight ratio was investigated as index of nutritional larval condition and survival potential. Proportions of larvae with TG indices $>0.2$ were relatively high in May 2000 and June 1999, but generally low in July 2000.
\end{abstract}

The fatty acids $16: 0,16: 1 n-7,18: 0,18: 1 n-9,18: 1 n-7,20: 5 n-3$, and 22:6n-3 were major lipid components of the larvae and their mean proportions varied within relatively small ranges between larval stages. The dominant fatty acids were 16:0, 20:5n-3, and 22:6n-3 with average proportions of about $17 \%, 20 \%$, and $13 \%$, as percentage of total fatty acids. Biomarkers for algae (16:0, 16:1n7, 18:1n-7, 20:5n-3, diatoms: elevated 16:1n-7/16:0 ratios), flagellates (18:0, 18:4n-3, 22:6n-3), and zooplankton $(18: 1 n-9,20: 1 n-9,22: 1 n-11)$ indicate that larval P. borealis and P. montagui are omnivorous.

ZI larvae in high concentrations at coastal and fjord stations in May 2000 and most larvae (ZIV-ZVI) from July 2000 were low in lipid. Larvae from June 1999 had relatively high lipid contents probably due to better feeding and growth history. Our results suggest variability in growth and survival expectations of larvae related to variations in larval food availability between years.

Keywords: biomarkers, condition, fatty acids, larval shrimp, lipids, Pandalus

\section{Introduction}

The food pathway in the pelagic marine ecosystem originates in the phytoplankton whose organic constituents are transformed by animals through food webs and different trophic levels (Nielsen and Hansen, 1995; Kiørboe, 2001). Lipid classes and fatty acid compositions generally characterise marine species or groups of organisms and they can be used to assess nutritional condition, survival expectations and trophic relationships at the different developmental stages (Lee et al., 1971a; Sargent and Whittle, 1981; Sargent et al., 1987; Sargent and Falk-Petersen, 1988; Kattner et al., 1994; Anger, 1998; Harding and Fraser, 
1999; Reuss and Poulsen, 2002). Lipid biomarkers have been found to be useful in the analyses of predator-prey relationships in food web studies (Graeve et al., 1994a,b; Kharlamenko et al., 1995; St. John and Lund, 1996; Graeve et al., 1997; Desvilettes et al., 1997; Falk-Petersen et al., 2000; Parrish et al.; 2000; Hamm et al., 2001; Arts et al., 2001). Ratios of 16:1n-7/16:0 have been positively correlated to lipid condition indices of juvenile fish, indicating a positive effect on growth and survival of diatom based food chains (St. John and Lund, 1996; Pedersen et al., 1999). St. John and Lund (1996) found juvenile cod in better lipid condition in frontal areas, dominated by diatoms, than outside frontal areas, characterized by various flagellates.

Relatively little is known about lipid contents, and trophic relationships of field collected Pandalid shrimp larvae (Stickney and Perkins, 1981; Harrison, 1990; Hopkins et al., 1993; Ouellet et al., 1995; Anger, 1998). According to Anger (1998) field studies of larval growth and development should be intensified to resolve uncertainty as to what extent laboratory data can be extrapolated to life in the natural environment. Distribution studies of larval shrimp have found wide larval dispersal and no association with specific hydrographic characteristics (Ouellet et al., 1990; Pedersen and Rice, 2002; Pedersen et al., 2002). This suggests that studies of food availability, physiological rates, and biochemical condition of individual larvae in specific water masses might be most important in determining survival and recruitment variability. According to Ouellet et al., (1992, 1995) a biochemical (lipid-based) condition index [i.e. larval triacylglycerols (TG) content $(\mu \mathrm{g})$ : wet weight $(\mathrm{mg})$ ratio $\mathrm{x}$ 1000] can reflect survival potential of larval $P$. borealis cohorts. This condition index may prove to be useful in assessing ecological factor(s) involved in recruitment processes of $P$. borealis populations.

Today the fishing industry as well as the economy in Greenland is mainly dependent on a large northern shrimp fishery, based on stable recruitment of new year-classes to the shrimp stock (e.g. Christensen and Vestergaard, 1993; Buch et al., 2002). Understanding processes and dynamics of the lower trophic levels of the marine pelagic food web during the productive period are one of the keys to understand changes in community structure and variability in recruitment success of shrimp and fish in the marine ecosystem (e.g. Cushing, 1989, 1995; Anderson, 2000; Pedersen et al., 2002).
The main purpose of this study was to investigate: 1) lipid class contents of different development stages of $P$. borealis and P. montagui larvae, 2) triacylglycerol $\left(\mathrm{TG} \mathrm{ww}^{-1}\right.$ ) as indices of nutritional condition, and 3 ) fatty acid compositions to establish trophic relationships. Questions we seek to answer are: Do lipid condition and fatty acid composition differ between the two dominant Pandalus species? Do specific prey (i.e. diatoms versus flagellates) carry a water-mass specific food web signal (fatty acid composition), which can be traced and related to good or bad lipid condition indices (survival expectations) in larval shrimp? Is variability in larval shrimp growth and survival coupled to variability in hydrographical processes and plankton production?

\section{Materials and Methods}

\section{Sampling}

Fresh $P$. borealis and $P$. montagui larvae were picked from zooplankton samples at selected stations during four research cruises carried out in June 1999, May 2000, and July 2000 between 63 $50^{\prime} \mathrm{N}$ and $66^{\circ} 50^{\prime} \mathrm{N}$ on the West Greenland shelf (see Pedersen et al., 2002). Stations were selected along transects (coast to offshore) to investigate variation in lipid contents of the larvae in relation to changes in the environment (temperature, salinity and abundance of potential larval food). The larvae were frozen individually in argon atmosphere in $2 \mathrm{ml}$ Eppendorf vials. On the June 1999 survey, the vials were frozen within few minutes after sampling and stored in a freezer $\left(-25^{\circ} \mathrm{C}\right)$. On three other surveys the vials were frozen in liquid nitrogen $\left(-196^{\circ} \mathrm{C}\right)$ for later determination of lipid contents in the laboratory. At the end of all cruises, the samples were immediately transferred to a biofreezer $\left(-80^{\circ} \mathrm{C}\right)$ until analysis.

\section{Biochemical analysis}

Lipid extraction was performed on individual larvae for 24 hours in $1.5 \mathrm{ml}$ chloroform/methanol $(2: 1 \mathrm{v} / \mathrm{v})$ at $-20^{\circ} \mathrm{C}$ with a known quantity of internal standard added (Ketone: Hexadecan-3-one). Additional lipid extraction of larvae for 24 hours in $1.5 \mathrm{ml}$ chloroform/methanol $(2: 1 \mathrm{v} / \mathrm{v})$ at $-20^{\circ} \mathrm{C} \mathrm{did}$ not produce further lipid from the larvae. The amount of internal standard was adjusted after the weight (lipid content) of the larvae. After lipid extraction the sample was centrifuged for 2 minutes (4000 rpm). The supernatant (lipid solution) was transferred to a 10 $\mathrm{ml}$ glass vial and the solvent was evaporated under a steam of argon gas. The retained lipid was then 
redissolved in hexane, transferred to a small glass vial, hexane evaporated under an argon flow and the dried lipid extract was stored at $-80^{\circ} \mathrm{C}$ until further analysis.

\section{Lipid classes}

For analysis of lipid class content, the lipid extract was resuspended in hexane and $1.4 \mu$ of the sample was spotted on a SIII-Chromarod for quantification using flame ionization detection with a model MK-5 IATROSCAN TLC/FID analyzer (Iatron, Laboratories Inc.) using Autospotter (SES 3200). For separation of the lipid classes, two different solvent systems were used to obtain two chromatograms per rod as described by Parrish (1987). The first solvent system, hexane:diethyl ether:formic acid (99:1:0.05), was used in a double development of $25 \mathrm{~min}$ followed by 20 min. Each rod was then scanned to after the internal standard (3-HEXADECANONE, Sigma product number: $\mathrm{H} 7504 \mathrm{H}$ ) peak to obtain the first chromatogram, which included: hydrocarbons (HC), wax esters (WE), methyl esters (ME) and the internal standard (KET). After a second 40-min development in hexane:diethyl ether:formic acid (80:20:0.1) the second chromatogram was obtained, containing peaks of triacylglycerols (TG), free fatty acids (FFA), alcohols (ALC), free sterols (ST) diacylglycerols (DG), and phospholipids (PL) plus non lipid material (NLM). After the second development the scan was continued to the end of the rod. However, for 30 random selected lipid samples from July (mainly stage $\mathrm{ZV}$ larvae) the scan was only continued to the lowest point behind the DG peak. These samples were developed in a third solvent system (40 min in chloroform:methanol:water, 15:10:1, v/v/v, S. Jónasdóttir, DIFRES, pers. comm.) to obtain a third chromatogram separating the PL and NLM. In average we found less than $4 \%$ NLM in the PL+NLM peaks. In order to test for overlaps of ST and DG (1,3-DG and 1,2-DG) peaks, and improve their separation, we tried an improved separation method described by Striby et al. (1999) on several lipid samples. However, for some unknown reason we were unable to separate mixtures of our standards of 1,3-DG and ST, and we gave up using this time-consuming extra separation method. Therefore, our estimated ST amounts may contain some 1,3-DG or 1,2 DG (see Striby et al., 1999), although we did find separate peaks of 1,3DG and 1,2 DG in the lipid samples. Before and between developments, the rods were humidified over saturated $\mathrm{NaCl}$ in order to maintain constant development qualities.
The quantification of each lipid constituent was based on calibration curves prepared from solutions of standard lipids obtained from Sigma Chemical Company (product number-name): HC (N 4129NONADECANE), WE (A 5885-ARACHIDIC ACID ARACHIDYL ESTER), TG (T 5016-TRISTEARIN), FFA (P 0500-PALMITIC ACID), 1,2 and 1,3-DG (D 8894-DIOLEIN and D 9019-DISTEARIN), ALC (P 3647-PHYTOL), ST (C 866-CHOLESTEROL), PL (P5014-PHOSPHATIDYLCHOLINE, DIHEPTANOYL). For each shrimp larva the analysis for lipids was run twice in order to minimize errors. In general, an average of the two calculations of lipid contents was used. In a few cases one of the calculations was unreliable and rejected.

\section{Fatty acids}

Fatty acid contents of selected individual larvae collected in May 2000 (stage ZI and ZII) and July 2000 (stage ZIV, ZV, and ZVI) were derived from all extracted lipids, whereas the extracted lipids of larvae of the June 1999 samples (stage ZIII and IV) were fractionated in three classes: neutral lipids (NL) free fatty acids (FFA) and phospholipids (PL). Fractionation was performed on Sep-Pak columns (Millipore) eluted with solvents of increasing polarity. Fatty acids were converted to methyl esters (FAME) by saponification and methylation with methanol and boron trifluoride as outlined in Refsgaard et al. (2000), but scaled down to the small lipid amounts of larval shrimp. To separate the aqueous and organic solvents the sample was mixed with $3 \mathrm{ml}$ saturated $\mathrm{NaCl}$ solution and $1 \mathrm{ml} n$-heptane. The upper heptane phase containing the fatty acids was transferred to gas chromatograph (GC) vials (method modified from Whyte, 1988). Analysis of individual fatty acid methyl esters was carried out on a HP 5890 gas chromatograph (Hewlett-Packard, Avondale, PA), equipped with a flame ionisation detector and an Omegawax 320 fused silica capillary column (0.32 $\mathrm{mm} \times 30 \mathrm{~m} \times 0.25 \mu \mathrm{m}$; Supelco, Bellefonte, PA). Splitless injection of $1-4 \mu \mathrm{l}$ was performed. The injection and detection temperatures were $200^{\circ} \mathrm{C}$ and $240^{\circ} \mathrm{C}$, respectively. The initial oven temperature program was (1) $80^{\circ} \mathrm{C}$ maintained for $1 \frac{1 / 2}{\mathrm{~min}}$, (2) ramp up to $160^{\circ} \mathrm{C}$ at a rate of $40^{\circ} \mathrm{C} \mathrm{min}^{-1}$, (3) a further increase to $240^{\circ} \mathrm{C}$ at a rate of $3^{\circ} \mathrm{C} \mathrm{min}^{-1}$ and (4) final temperature maintained for $12 \mathrm{~min}$. The helium carrier gas flow was $21 \mathrm{~cm} \mathrm{~s}^{-1}$. Fatty acid methyl esters were identified based on a comparison with retention times of standards obtained from Sigma and Larodan, 
and standard runs of saturated even and odd chained fatty acids. Quantification was performed by a Perkin Elmer NCI 900 integrator with Turbochrom 4.0 software (Perkin Elmer Inc.). Mass spectrometry was not used to confirm identities of individual fatty acids.

\section{Data analysis}

Discrimination between $P$. borealis and P. montagui was based on the size criteria given in Pedersen et al. (2002). Lipid class content (HC, WE, TG, FFA, ALC, ST, DG and PL) relative to wet weight of individual larvae was investigated for variation among species, size, stage, sampling station, transect, and month using multi- and one-way ANOVA (SAS, 1985; GLM procedure).

We chose to differentiate larvae of TG condition index $\mathrm{ww}^{-1}$ below and above 0.2 , because 0.2 may be a critical level for larval shrimp survival (Ouellet et al., 1992, 1995). Associations among potential larval food densities (integrated fluorescens values, number $\mathrm{m}^{-2}$ of copepod eggs, -nauplii, and copepodites, and other invertebrate larvae), larval shrimp density (number $\mathrm{m}^{-2}$ ), and lipid condition indices were investigated using Sperman rank correlations analysis. Potential larval food, and shrimp larvae concentrations are reported in Pedersen et al. (2002).

Cluster analysis (Bray-Curtis similarity) and Principal Components Analysis (PCA) were performed to evaluate the similarities and groupings of the fatty acid frequency compositions of individual shrimp larvae by lipid classes (NL, FFA, and PL for June 1999 larvae, only), species, zoeal stage, station, and sampling month using the software PRIMER v. 5.0 (Clarke and Warwick, 1994).

\section{Results}

\section{Lipid class content}

The lipids of the zoeal stages of $P$. borealis and P. montagui were dominated by phospho-lipids (Tables 1 and 2). WE and ALC were present in low amounts in all stages. For ZI and ZII larvae, the second most abundant lipid class was HC followed by ST, FFA, TG, and 1,2DG. For ZIII and ZIV larvae from June, the second most abundant lipid class was FFA followed by ST, HC, TG, and 1,2DG. For ZV, ZVI, and VII from July, ST was the second most abundant followed by FFA, DG (1,2 and 1,3), HC, and TG (Appendix figure).

There was a marked difference in lipid contents between the June 1999 and July 2000 larvae, the amounts of lipids being much higher in June 1999 (Tables 1 and 2). Total lipid of ZIV larvae from June 1999 were in fact higher than of stage ZV larvae from July 2000, due to higher amounts of FFA, PL, and TG. The relative high FFA content found in the larvae collected in June 1999 could indicate enzymatic hydrolysis of PL due to improper freezing and storage of the larvae samples (Ohman, 1996). Pandalids are known to have high enzymatic activity. In June 1999, live larval shrimp were frozen in argon atmosphere in a $-25^{\circ} \mathrm{C}$ freezer for 2 weeks before transferred to a biofreezer after the cruise. This may have caused lipid degradation and FFA formation.

\section{Lipid condition indices}

The individual ratios of lipid content to wet weight by larval size and lipid class showed trends and variations. With increasing larval size from hatching to a carapace length (cl) of $\sim 2.3 \mathrm{~mm}$ there was a decreasing trend in the HC lipid content. From a larval size above $\sim 2.5 \mathrm{~mm}$ cl the ST to wet weight ratio showed an increasing trend. The TG, 1,2DG, FFA, ALC, and PL contents to wet weight ratios with larval size showed variations with no clear trends.

Two lipid condition indices, 1) TG $\mathrm{ww}^{-1} \times 1000$, and 2) $\mathrm{HC}+\mathrm{TG}+\mathrm{FFA}+\mathrm{ALC}+\mathrm{DG} \mathrm{ww}^{-1} \times 1000$ (hereafter referred to as the TG and Lipcon index, respectively), were investigated for variations among species, stage, sampling station, transect, and month using multiand one-way ANOVA. The TG and Lipcon indices were significantly correlated in larvae collected in May 2000 and July 2000, but not in larvae collected in June 1999 (Fig. 1).

ZI larvae from May 2000 were not identified to species, and ANOVA of the TG indices $\left(n=146, r^{2}=\right.$ $0.48, F=8.04, p(p>F)<0.001)$ showed no significant $(p>0.05)$ effects of stage (ZI larvae: $n=142$, and ZII larvae: $n=4$ ) or sampling location (transect). However, a few stations had significant higher TG indices: 1) the ocean ward stations of transect 1 (TR1), 2) a station on the inner edge of Sukkertop Bank on transect 3 (TR3), and 3) two fjord stations.

ANOVA of TG indices from June $1999(n=63$, $\left.r^{2}=0.55, F=5.12, p(p>F)<0.001\right)$ showed significant $(p<0.05)$ effects of species, stage, and sampling station. The smaller $P$. montagui larvae generally had higher TG indices than P. borealis larvae, and ZIII larvae having higher TG indices than ZIV larvae. A few stations west of the banks on $\operatorname{Tr} 2$ and $\operatorname{Tr} 3$ had significantly higher TG indices compared to the mean 
TABLE 1. Comparison of wet weight, carapace length, and contents of lipid classes of "large" larvae, P. borealis, by zoeal stage, sampling month and year (mean \pm SE of $\mathrm{N}$ individuals). Zoeal stage I includes both $P$. borealis and $P$. montagui larvae. $\mathrm{HC}=$ hydrocarbons, $\mathrm{WE}=$ wax esters, $\mathrm{TG}=$ triacylglycerols, FFA $=$ free fatty acids, ALC = alcohols, 1,3 DG = 1,3 diacylglycerol, ST = free sterols, 1, 2DG = 1,2 diacylglycerol, $\mathrm{PL}=$ phospholipids.

\begin{tabular}{|c|c|c|c|c|c|c|c|}
\hline Zoeal stage & $\mathrm{ZI}$ & ZII & ZIII & ZIV & ZIV & ZV & ZVI \\
\hline Month(year) & May(2000) & May(2000) & June(1999) & June(1999) & July(2000) & July(2000) & July(2000) \\
\hline $\mathrm{N}$ & 142 & 4 & 17 & 32 & 2 & 58 & 37 \\
\hline Carapace length (mm) & $1.4 \pm 0.0$ & $1.7 \pm 0.1$ & $2.5 \pm 0.0$ & $3.1 \pm 0.0$ & $2.7 \pm 0.0$ & $3.1 \pm 0.0$ & $3.7 \pm 0.0$ \\
\hline Wet weight (mg) & $1.8 \pm 0.1$ & $2.4 \pm 0.3$ & $6.3 \pm 0.2$ & $9.8 \pm 0.3$ & $6.6 \pm 0.2$ & $12.8 \pm 0.3$ & $18.4 \pm 0.5$ \\
\hline \multicolumn{8}{|l|}{ Lipid classes: } \\
\hline $\mathrm{HC}(\mu \mathrm{g})$ & $5.0 \pm 0.2$ & $3.8 \pm 0.3$ & $3.0 \pm 0.3$ & $2.3 \pm 0.2$ & $4.1 \pm 1.0$ & $4.3 \pm 0.2$ & $5.2 \pm 0.3$ \\
\hline WE $(\mu \mathrm{g})$ & $0.2 \pm 0.0$ & $0.1 \pm 0.1$ & $0.0 \pm 0.0$ & $0.1 \pm 0.1$ & $0.5 \pm 0.3$ & $0.4 \pm 0.1$ & $0.5 \pm 0.1$ \\
\hline TG $(\mu \mathrm{g})$ & $1.0 \pm 0.1$ & $0.8 \pm 0.2$ & $3.2 \pm 0.6$ & $3.1 \pm 0.3$ & $0.6 \pm 0.1$ & $2.0 \pm 0.1$ & $3.0 \pm 0.4$ \\
\hline FFA $(\mu g)$ & $2.6 \pm 0.2$ & $3.4 \pm 0.4$ & $36.5 \pm 3.2$ & $49.0 \pm 4.6$ & $4.3 \pm 0.6$ & $16.0 \pm 1.2$ & $21.1 \pm 1.9$ \\
\hline ALC $(\mu g)$ & $0.2 \pm 0.0$ & $0.1 \pm 0.1$ & $0.6 \pm 0.3$ & $1.3 \pm 0.3$ & $1.0 \pm 1.0$ & $0.2 \pm 0.1$ & $0.7 \pm 0.6$ \\
\hline $1,3 \mathrm{DG}(\mu \mathrm{g})$ & $0.1 \pm 0.0$ & $0.1 \pm 0.1$ & $0.0 \pm 0.0$ & $0.0 \pm 0.0$ & $0.0 \pm 0.0$ & $5.7 \pm 0.7$ & $9.0 \pm 1.4$ \\
\hline ST ( $\mu g)$ & $3.4 \pm 0.2$ & $4.0 \pm 0.7$ & $12.2 \pm 0.8$ & $22.8 \pm 1.5$ & $19.9 \pm 2.3$ & $69.3 \pm 3.3$ & $100.6 \pm 4.9$ \\
\hline $1,2 \mathrm{DG}(\mu \mathrm{g})$ & $0.8 \pm 0.1$ & $1.0 \pm 0.3$ & $1.5 \pm 0.1$ & $3.3 \pm 0.3$ & $3.3 \pm 3.3$ & $1.2 \pm 0.6$ & $4.7 \pm 1.5$ \\
\hline $\mathrm{PL}(\mu \mathrm{g})$ & $81.7 \pm 5.5$ & $87.7 \pm 13.8$ & $426.3 \pm 27.7$ & $926.0 \pm 86.1$ & $235.8 \pm 98.3$ & $713.7 \pm 33.0$ & $962.2 \pm 74.6$ \\
\hline Total lipid $(\mu g)$ & $94.8 \pm 6.0$ & $101.1 \pm 14.0$ & $485.0 \pm 27.9$ & $1009.8 \pm 87.9$ & $269.3 \pm 96.3$ & $812.8 \pm 35.4$ & $1106.9 \pm 75.2$ \\
\hline
\end{tabular}

TABLE 2. Comparison of wet weight, carapace length, and contents of lipid classes of "small" larvae, P. montagui, by zoeal stage, sampling month and year (mean $\pm \mathrm{SE}$ of $\mathrm{N}$ individuals).

\begin{tabular}{lcccr}
\hline \hline Zoeal stage & ZIV & ZIV & ZV & ZVI \\
Month(year) & June $(1999)$ & July(2000) & July(2000) & July(2000) \\
$\mathrm{N}$ & 13 & 17 & 41 & \multicolumn{1}{c}{45} \\
\hline Carapace length $(\mathrm{mm})$ & $2.3 \pm 0.1$ & $2.0 \pm 0.1$ & $2.5 \pm 0.1$ & $3.0 \pm 0.0$ \\
Wet weight $(\mathrm{mg})$ & $5.6 \pm 0.5$ & $4.4 \pm 0.2$ & $7.5 \pm 0.4$ & $11.6 \pm 0.5$ \\
Lipid classes: & & & & \\
\cline { 2 - 5 } HC $(\mu \mathrm{g})$ & $2.2 \pm 0.2$ & $3.5 \pm 0.3$ & $3.5 \pm 0.2$ & $4.4 \pm 0.3$ \\
WE $(\mu \mathrm{g})$ & $0.0 \pm 0.0$ & $0.1 \pm 0.1$ & $0.3 \pm 0.1$ & $0.4 \pm 0.1$ \\
TG $(\mu \mathrm{g})$ & $3.5 \pm 0.4$ & $0.9 \pm 0.4$ & $1.9 \pm 0.6$ & $2.3 \pm 0.6$ \\
FFA $(\mu \mathrm{g})$ & $45.4 \pm 19.1$ & $2.8 \pm 0.8$ & $7.4 \pm 0.9$ & $12.0 \pm 1.2$ \\
ALC $(\mu \mathrm{g})$ & $0.8 \pm 0.4$ & $0.0 \pm 0.0$ & $0.6 \pm 0.4$ & $1.0 \pm 0.5$ \\
$1,3 \mathrm{DG}(\mu \mathrm{g})$ & $0.0 \pm 0.0$ & $0.3 \pm 0.2$ & $2.2 \pm 0.4$ & $4.6 \pm 0.8$ \\
ST $(\mu \mathrm{g})$ & $10.9 \pm 1.5$ & $10.2 \pm 1.1$ & $27.9 \pm 2.9$ & $51.5 \pm 4.2$ \\
$1,2 \mathrm{DG}(\mu \mathrm{g})$ & $1.2 \pm 0.2$ & $4.3 \pm 0.5$ & $1.8 \pm 0.4$ & $5.8 \pm 1.1$ \\
PL $(\mu \mathrm{g})$ & $499.7 \pm 85.4$ & $209.7 \pm 19.4$ & $398.2 \pm 35.5$ & $610.4 \pm 48.0$ \\
Total lipid $(\mu \mathrm{g})$ & $566.4 \pm 86.1$ & $231.9 \pm 19.9$ & $443.8 \pm 38.4$ & $692.3 \pm 51.8$ \\
\hline
\end{tabular}

value. ANOVA of Lipcon indices from June 1999 ( $n$ $\left.=63, r^{2}=0.56, F=5.25, p(p>F)<0.001\right)$ showed significant effects of species, and station, but no significant effect of stage. There was a significant higher mean Lipcon index on the westernmost station of $\operatorname{Tr} 3$.

ANOVA of TG indices from July $2000(n=197$, $\left.r^{2}=0.07, F=0.58, p(p>F)<0.943\right)$ showed no significant $(p>0.05)$ effects of species, stage, or sampling station. This result excludes one station (three larvae) with significant and exceptional high TG indices.

The proportions of larvae with TG indices $>0.2$ were relatively high in May 2000 and June 1999, but generally low in July 2000 (Fig. 2). In May and June, the proportions of larvae with TG indices $>0.2$ were highest on the western transect stations. ZIV larvae in June 1999 were generally in better lipid condition than in July 2000, and the smaller P. montagui larvae were in better lipid condition than P. borealis (Fig. 3 ). In fact nearly all investigated $P$. borealis from July 2000 had a TG index below 0.2 .

\section{Fatty acid compositions (FAC)}

The larvae analysed for FAC were selected from stations in June 1999, May, and July 2000 (Fig. 2 number of analysed larvae in brackets). Lipid samples of ZIII and ZIV larvae collected in June 1999 were fractionated in three classes: neutral lipids (NL) free fatty acids (FFA) and phospholipids (PL). Bray-Curtis 

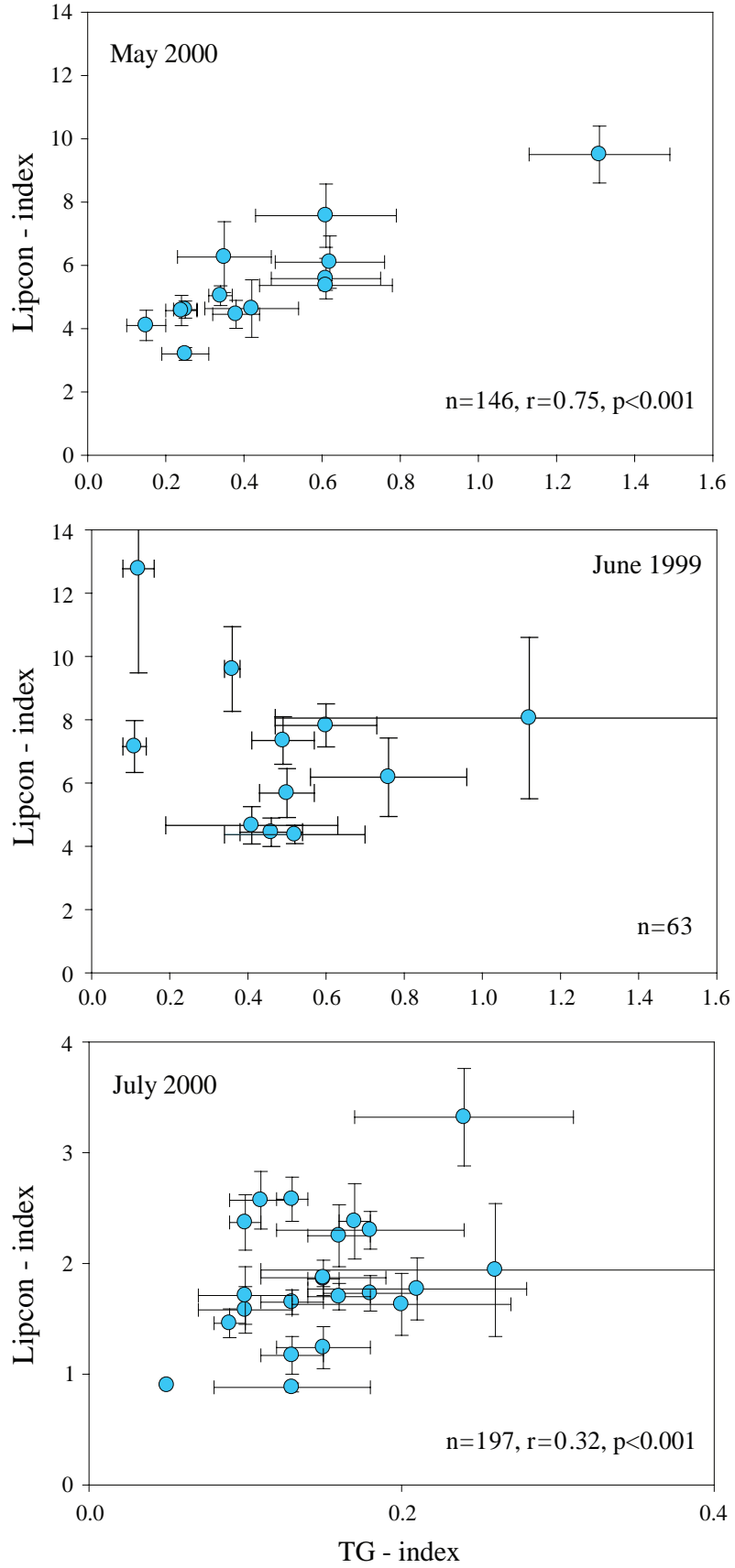

Fig. 1. Mean $( \pm \mathrm{SE}) \mathrm{TG}$-index versus mean $( \pm \mathrm{SE})$ Lipconindex in May 2000, June 1999, and July 2000. Significant correlation coefficients in May and July are shown.

similarity indices and PCA showed no clear or consistent differences between the FACs of individual larvae by the lipid classes NL, FFA, and PL. Therefore, FACs of individual larvae collected in May and July 2000 were analysed in total lipid, only. Hence, the comparisons of similarities and groupings of the FACs of individual larvae were made for total lipid.
The fatty acids $14: 0,16: 0,16: 1 n-7,18: 0,18: 1 n-$ 9, 18:1n-7, 18:2n-6, 18:4n-3, 20:1n-9, 20:5n-3, and 22:6n-3 were major lipid components of the larvae (Table 3 ). Their mean proportions varied within relative small ranges between larval stages. There was no difference in fatty acid composition between $P$. borealis and $P$. montagui.

The dominant fatty acids were 16:0, 20:5n-3, and $22: 6 n-3$ with average proportions of about $17 \%, 20 \%$, and $13 \%$, as percentage of total fatty acids. The FACs showed a high proportion of polyunsaturated fatty acid (PUFA) in all larval stages, mainly PUFAn-3 (Table 3 ). The proportions of the monounsaturated fatty acids (MUFA) 20:1n-9 and 22:1n-11 were generally highest in ZIV larvae collected in June 1999. C18-PUFA showed an increase from in average $2.9 \%$ in $\mathrm{ZI}$ to about $8 \%$ in ZIII-ZVI larvae. Contents of C18 fatty acids showed significant correlation with flagellate abundance and may be considered a biomarker for flagellates (see Reuss and Poulsen, 2002). ANOVA of proposed diatom biomarkers, ratios of 16:1n-7/16:0, 20:5n-3/18:4n-3, and 20:5n-3/22:6n-3, showed no significant effects of sampling month, stage, and species.

Bray-Curtis similarity indices of the FACs of individual larvae showed generally higher similarities among ZIV, ZV, and ZVI larvae, compared to ZI larvae (Fig. 4). Larvae were generally grouped by stage and sampling station. However, ZIV larvae from stations in June 1999 showed high similarities with ZVI larvae from stations in July 2000. The FACs of ZI larvae collected at a coastal and a fjord station differed from offshore collected ZI larvae from May 2000 (Fig. 4). The coastal and fjord stations both had high larval abundance, low TG condition, lower proportions of $16: 0,16: 1 n-7,20: 5 n-3,22: 6 n-3$, and higher proportions of 18:0, compared to offshore collected ZI larvae.

\section{Lipid content and potential larval shrimp food}

The FACs of individual larvae from June 1999 and May 2000 were compared with FACs of plankton $<300 \mu \mathrm{m}$ collected at the same station. For a detailed description of the FACs of plankton $<300 \mu \mathrm{m}$, see Reuss and Poulsen (2002). Bray-Curtis similarity between FACs of shrimp larvae and plankton $<300 \mu \mathrm{m}$ were from 55 to $78 \%$ in June 1999, and from 55 to $68 \%$ in May 2000. In May, fatty acid compositions of shrimp larvae and plankton $<300 \mu \mathrm{m}$ from two costal stations clustered (the innermost station of $\operatorname{Tr} 1$ and a station in the entrance to Godthåbsfjord, Fig. 2), and 

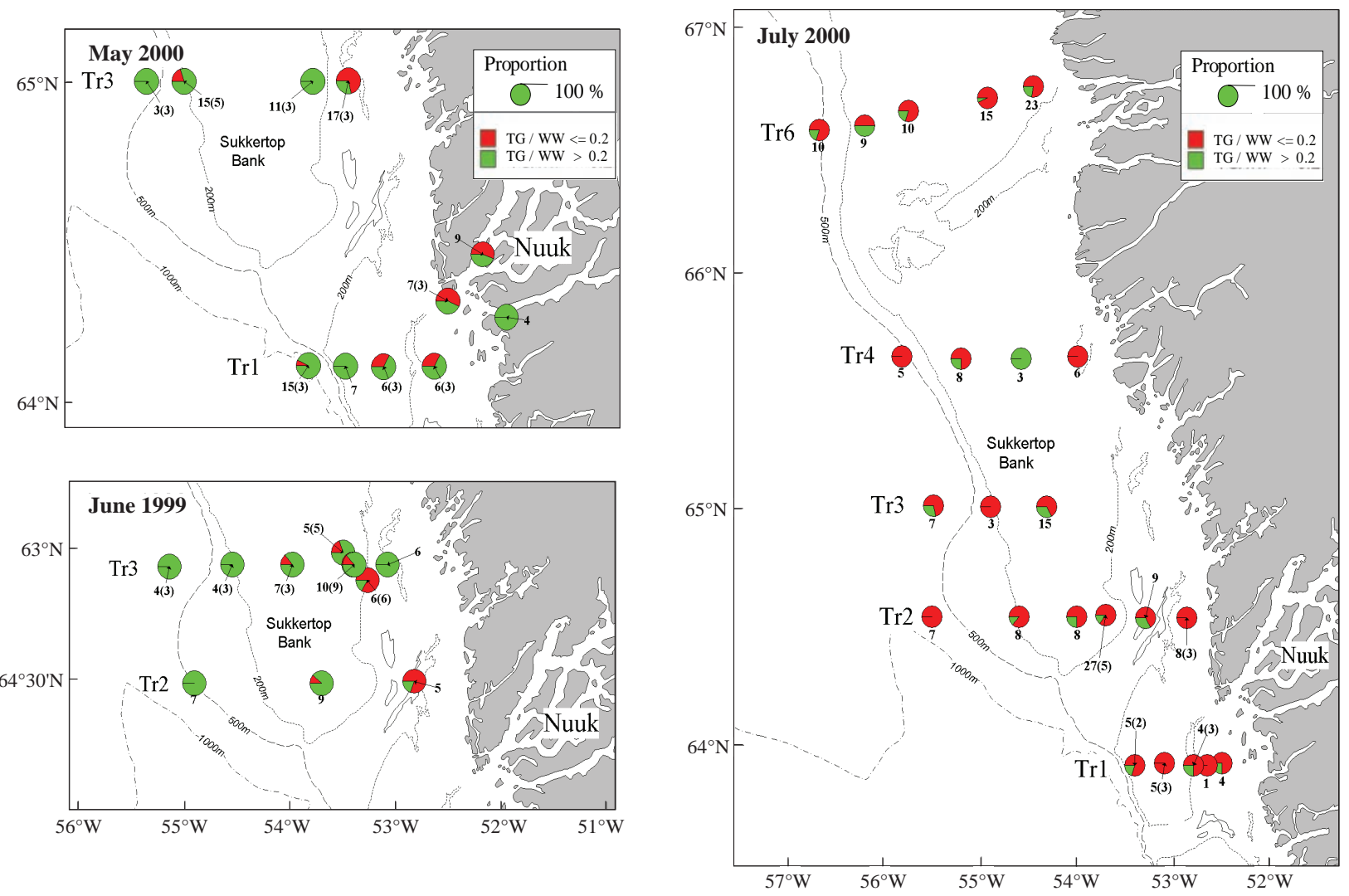

Fig. 2. Proportion of TG-indices in shrimp larvae from May 2000, June 1999 and July 2000. TG index >0.2 (green), and TG index $\leq 0.2$ (red). Number of samples (individual larvae) shown below dots. Number in brackets shows the number of larvae analysed for fatty acid composition.

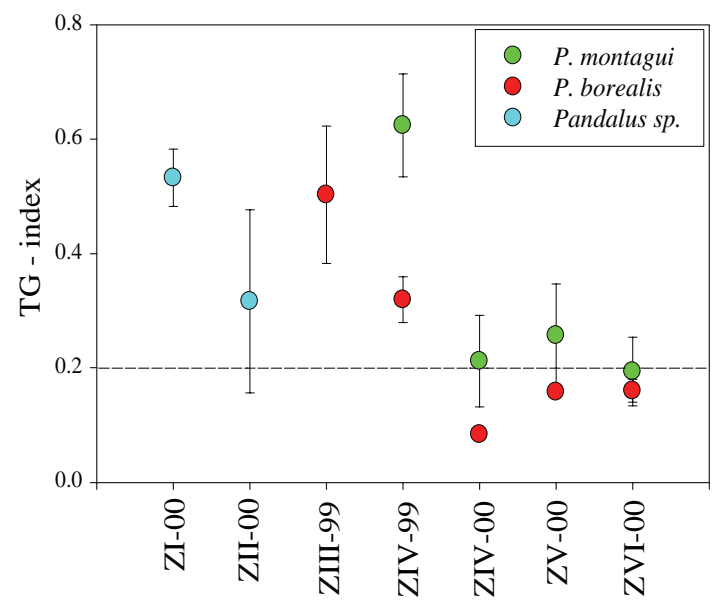

Fig. 3. Mean TG indices ( \pm SE) by zoeal stage, sampling year, and species. Zoeal stage I and II includes both $P$. borealis and P. montagui larvae. TG 0.2 is critical level. all other mainly offshore samples of shrimp larvae and plankton $<300 \mu \mathrm{m}$ clustered.

There was a significant positive correlation between the diatom biomarker, 16:1n-7/16:0 ratio, found in larval shrimp and in plankton $<300 \mu \mathrm{m}$ for May $(n=26, r=0.41, p=0.04)$ and June $(n=29$, $r=0.74, p<0.01)$. For May, only, there was also a significant positive correlation between the percentages of $\mathrm{C} 18$ fatty acids in shrimp larvae and in plankton $<300 \mu \mathrm{m}(n=26, r=0.45, p=0.02)$.

In the shrimp larvae, the diatom biomarker, 16: $1 \mathrm{n}-7 / 16: 0$ ratio, and the flagellate biomarker, \%C18, showed no significant correlation in May, June or July. However, the diatom biomarker 20:5n-3/18:4n-3 ratio and $\% \mathrm{C} 18$ showed significant correlations in May $(n=28, r=-0.38, p=0.05)$, June $(n=29, r=-0.78$, 
TABLE 3. Fatty acid composition (mean mass $\% \pm \mathrm{SD}$ of $\mathrm{N}$ individuals) of total lipid of P. borealis and P. montagui larvae by species, zoeal stage and sampling month (year).

\begin{tabular}{|c|c|c|c|c|c|c|c|c|}
\hline \multirow[b]{2}{*}{$\begin{array}{l}\text { Zoeal stage } \\
\text { Month(Year) }\end{array}$} & \multirow[b]{2}{*}{$\begin{array}{r}\text { ZI } \\
\text { May(2000) }\end{array}$} & \multicolumn{4}{|c|}{ P. borealis } & \multicolumn{3}{|c|}{ P. montagui } \\
\hline & & $\begin{array}{r}\text { ZIII } \\
\text { June(1999) }\end{array}$ & $\begin{array}{r}\text { ZIV } \\
\text { June(1999) }\end{array}$ & $\begin{array}{r}\text { ZV } \\
\text { July(2000) }\end{array}$ & $\begin{array}{r}\text { ZVI } \\
\text { July(2000) }\end{array}$ & $\begin{array}{r}\text { ZIV } \\
\text { June(1999) }\end{array}$ & $\begin{array}{r}\text { ZV } \\
\text { July(2000) }\end{array}$ & $\begin{array}{l}\text { ZVI } \\
\text { July(2000) }\end{array}$ \\
\hline $\mathrm{N}$ & 29 & 3 & 20 & 4 & 3 & 5 & 4 & 5 \\
\hline Carapace length (mm) & $1.4 \pm 0.3$ & $2.4 \pm 0.1$ & $3.2 \pm 0.1$ & $3.2 \pm 0.2$ & $3.6 \pm 0.0$ & $2.4 \pm 0.1$ & $2.7 \pm 0.3$ & $2.9 \pm 0.3$ \\
\hline $\begin{array}{l}\text { Wet weight (mg) } \\
\text { Fatty acid (mass \%): }\end{array}$ & $1.7 \pm 0.7$ & $7.0 \pm 1.5$ & $9.4 \pm 2.4$ & $13.7 \pm 1.0$ & $17.5 \pm 2.0$ & $5.5 \pm 0.3$ & $7.6 \pm 1.9$ & $11.5 \pm 4.3$ \\
\hline $13: 0$ & $1.9 \pm 5.6$ & $1.4 \pm 0.4$ & $0.4 \pm 0.4$ & $0.0 \pm 0.0$ & $0.5 \pm 0.2$ & $0.6 \pm 0.9$ & $0.0 \pm 0.0$ & $0.1 \pm 0.3$ \\
\hline 14:0 & $2.4 \pm 0.9$ & $4.5 \pm 0.4$ & $5.3 \pm 1.2$ & $4.8 \pm 0.5$ & $4.6 \pm 0.5$ & $4.7 \pm 0.6$ & $4.2 \pm 0.4$ & $4.7 \pm 0.4$ \\
\hline $16: 0$ & $17.2 \pm 4.7$ & $15.3 \pm 1.5$ & $19.7 \pm 3.0$ & $21.1 \pm 4.5$ & $19.0 \pm 0.8$ & $16.7 \pm 1.3$ & $21.8 \pm 4.5$ & $20.0 \pm 4.9$ \\
\hline $17: 0$ & $1.3 \pm 1.6$ & $2.3 \pm 0.1$ & $2.4 \pm 1.3$ & $0.3 \pm 0.2$ & $0.4 \pm 0.0$ & $3.0 \pm 1.6$ & $0.5 \pm 0.2$ & $0.2 \pm 0.2$ \\
\hline $18: 0$ & $7.2 \pm 7.1$ & $5.5 \pm 2.1$ & $4.1 \pm 0.9$ & $3.7 \pm 1.2$ & $2.9 \pm 0.4$ & $6.4 \pm 2.2$ & $3.9 \pm 1.3$ & $2.6 \pm 1.7$ \\
\hline $20: 0$ & $3.5 \pm 5.2$ & $0.5 \pm 0.8$ & $0.3 \pm 0.5$ & $0.1 \pm 0.0$ & $0.1 \pm 0.0$ & $0.0 \pm 0.0$ & $0.2 \pm 0.1$ & $0.2 \pm 0.1$ \\
\hline$\%$ SAFA & $33.3 \pm 9.3$ & $29.6 \pm 2.4$ & $32.2 \pm 5.6$ & $29.9 \pm 6.0$ & $27.4 \pm 0.7$ & $31.4 \pm 2.6$ & $30.7 \pm 6.0$ & $27.9 \pm 5.6$ \\
\hline $16: 1 n-7$ & $4.5 \pm 2.3$ & $4.7 \pm 1.0$ & $6.4 \pm 2.8$ & $5.7 \pm 2.6$ & $5.5 \pm 0.7$ & $4.1 \pm 0.9$ & $4.3 \pm 2.3$ & $7.0 \pm 2.5$ \\
\hline $18: 1 n-9$ & $5.9 \pm 1.9$ & $17.3 \pm 14$ & $7.3 \pm 1.7$ & $8.8 \pm 4.3$ & $8.9 \pm 2.4$ & $12.6 \pm 8.4$ & $10.4 \pm 2.6$ & $8.8 \pm 3.3$ \\
\hline $18: 1 n-7$ & $6.1 \pm 2.4$ & $3.9 \pm 0.9$ & $4.9 \pm 1.0$ & $4.7 \pm 0.3$ & $5.2 \pm 0.2$ & $4.0 \pm 0.2$ & $4.4 \pm 2.0$ & $3.2 \pm 2.4$ \\
\hline $20: 1 n-9$ & $0.7 \pm 0.5$ & $2.8 \pm 0.7$ & $3.6 \pm 1.3$ & $1.9 \pm 1.4$ & $2.1 \pm 0.4$ & $3.9 \pm 0.9$ & $1.5 \pm 2.0$ & $2.0 \pm 1.3$ \\
\hline $22: 1 n-11$ & $0.8 \pm 1.3$ & $0.2 \pm 0.1$ & $3.2 \pm 2.6$ & $1.0 \pm 1.0$ & $1.0 \pm 0.2$ & $1.6 \pm 0.5$ & $0.7 \pm 0.3$ & $1.2 \pm 0.8$ \\
\hline $22: 1 n-9$ & $0.2 \pm 0.1$ & $1.7 \pm 0.9$ & $0.6 \pm 0.5$ & $0.4 \pm 0.1$ & $0.3 \pm 0.1$ & $1.4 \pm 1.5$ & $0.2 \pm 0.1$ & $0.4 \pm 0.3$ \\
\hline $24: 1 n-9$ & $2.2 \pm 3.1$ & $0.5 \pm 0.6$ & $0.2 \pm 0.4$ & $0.0 \pm 0.0$ & $0.0 \pm 0.0$ & $0.4 \pm 0.6$ & $0.0 \pm 0.0$ & $0.0 \pm 0.0$ \\
\hline \%MUFA & $20.4 \pm 6.9$ & $31.1 \pm 15$ & $26.2 \pm 6.2$ & $22.5 \pm 1.3$ & $23.0 \pm 1.1$ & $28.1 \pm 11$ & $21.4 \pm 3.7$ & $22.6 \pm 3.7$ \\
\hline $16: 2$ & $3.5 \pm 5.1$ & $0.2 \pm 0.2$ & $0.5 \pm 0.4$ & $0.3 \pm 0.1$ & $0.3 \pm 0.1$ & $0.5 \pm 0.6$ & $0.3 \pm 0.2$ & $0.4 \pm 0.3$ \\
\hline $18: 2 n-6$ & $1.1 \pm 0.8$ & $3.1 \pm 0.9$ & $2.3 \pm 0.3$ & $2.9 \pm 0.6$ & $2.3 \pm 0.1$ & $2.4 \pm 0.5$ & $2.7 \pm 0.3$ & $2.9 \pm 1.0$ \\
\hline $18: 3 n-3$ & $0.3 \pm 0.3$ & $0.9 \pm 0.3$ & $0.7 \pm 0.2$ & $1.4 \pm 0.4$ & $1.5 \pm 0.3$ & $0.8 \pm 0.2$ & $1.4 \pm 0.5$ & $1.1 \pm 0.4$ \\
\hline $18: 4 n-3$ & $1.4 \pm 2.0$ & $4.2 \pm 0.6$ & $3.0 \pm 1.6$ & $4.5 \pm 1.1$ & $3.6 \pm 0.8$ & $6.2 \pm 1.6$ & $4.0 \pm 2.0$ & $2.6 \pm 0.8$ \\
\hline $20: 2 n-6$ & $1.3 \pm 1.4$ & $0.1 \pm 0.1$ & $0.2 \pm 0.1$ & $0.4 \pm 0.1$ & $0.3 \pm 0.1$ & $0.2 \pm 0.1$ & $0.3 \pm 0.1$ & $0.4 \pm 0.1$ \\
\hline $20: 5 n-3$ & $20.8 \pm 8.3$ & $11.8 \pm 5.8$ & $17.4 \pm 5.8$ & $21.4 \pm 5.3$ & $24.1 \pm 1.2$ & $15.6 \pm 5.3$ & $23.0 \pm 3.2$ & $24.8 \pm 3.2$ \\
\hline $22: 5 n-3$ & $2.0 \pm 2.3$ & $0.2 \pm 0.1$ & $0.4 \pm 0.1$ & $0.4 \pm 0.1$ & $0.5 \pm 0.1$ & $0.2 \pm 0.1$ & $0.4 \pm 0.1$ & $0.4 \pm 0.1$ \\
\hline $22: 6 n-3$ & $8.9 \pm 4.0$ & $13.7 \pm 10$ & $12.4 \pm 4.6$ & $13.6 \pm 2.5$ & $14.5 \pm 1.0$ & $11.1 \pm 2.0$ & $12.8 \pm 1.1$ & $13.9 \pm 1.5$ \\
\hline \%PUFA n-3 & $34.4 \pm 10$ & $31.5 \pm 13$ & $34.6 \pm 11$ & $42.2 \pm 6.5$ & $44.9 \pm 1.4$ & $34.3 \pm 8.1$ & $42.5 \pm 4.1$ & $43.5 \pm 4.5$ \\
\hline \% Unknown & $5.5 \pm 5.0$ & $3.8 \pm 0.7$ & $3.2 \pm 0.8$ & $2.7 \pm 0.7$ & $2.9 \pm 0.5$ & $2.8 \pm 0.6$ & $2.8 \pm 1.1$ & $3.5 \pm 1.9$ \\
\hline \%other* & $2.5 \pm 1.7$ & $1.3 \pm 0.5$ & $1.4 \pm 0.3$ & $1.8 \pm 0.2$ & $1.6 \pm 0.2$ & $0.9 \pm 0.5$ & $1.7 \pm 0.1$ & $1.6 \pm 1.6$ \\
\hline $18: 1 n-9 / 18: 1 n-7$ & $1.3 \pm 1.3$ & $4.2 \pm 3.0$ & $1.5 \pm 0.4$ & $2.2 \pm 0.6$ & $1.8 \pm 0.4$ & $3.2 \pm 1.9$ & $2.6 \pm 2.3$ & $3.8 \pm 2.8$ \\
\hline $16: 1 n-7 / 16: 0$ & $0.3 \pm 0.1$ & $0.3 \pm 0.0$ & $0.3 \pm 0.1$ & $0.3 \pm 0.2$ & $0.3 \pm 0.0$ & $0.2 \pm 0.0$ & $0.2 \pm 0.2$ & $0.4 \pm 0.2$ \\
\hline $20: 5 n-3 / 18: 4 n-3$ & $25.8 \pm 17$ & $2.8 \pm 1.5$ & $7.1 \pm 4.5$ & $5.2 \pm 2.4$ & $7.0 \pm 1.7$ & $2.5 \pm 0.6$ & $7.1 \pm 4.0$ & $10.6 \pm 4.2$ \\
\hline $20: 5 n-3 / 22: 6 n-3$ & $2.8 \pm 1.5$ & $1.1 \pm 0.6$ & $1.5 \pm 0.5$ & $1.6 \pm 0.1$ & $1.7 \pm 0.1$ & $1.4 \pm 0.3$ & $1.8 \pm 0.2$ & $1.8 \pm 0.3$ \\
\hline C18PUFA/16:1n-7 & $1.0 \pm 1.2$ & $1.8 \pm 0.5$ & $1.1 \pm 0.4$ & $1.9 \pm 1.2$ & $1.3 \pm 0.2$ & $2.3 \pm 0.5$ & $2.4 \pm 1.2$ & $1.2 \pm 1.0$ \\
\hline
\end{tabular}

*Other components: 15:0, 16:4(n-3), 20:4(n-6), 20:3(n-3), 20:4(n-3). Mass spectrometry was not used to confirm identities of individual fatty acids.

$p<0.01)$, and July ( $n=16, r=-0.81, p<0.01)$. The diatom biomarkers showed correlations with each other only in June between 16:1n-7/16:0 and 20:5n3/22:6n-3 ( $n=29, r=0.55, p<0.01)$, and in July between $20: 5 n-3 / 18: 4 n-3$ and $20: 5 n-3 / 22: 6 n-3(n=$ $16, r=0.75, p<0.01)$.

We found no significant correlations between diatom biomarkers and the larval lipid condition indices ( $\mathrm{TG} \mathrm{ww}^{-1}$ and Lipcon $\mathrm{ww}^{-1}$ ). However, in June 1999 , highest $16: 1 \mathrm{n}-7 / 16: 0$ ratios were found in larvae caught on the westernmost station of Tr3. Larvae from this station had relatively high TG- and Lipcon indices, the latter dominated by FFA. This station also showed the highest potential food concentrations of phytoplankton, copepod egg, nauplii, copepodites, and other invertebrate larvae (see Pedersen et al., 2002), indicating a link between food concentration and larval shrimp lipid condition. Attempts to associate larvae lipid condition from May and July 2000 with indices of potential food concentrations failed. In May 2000 , there was a significant negative correlation between TG indices and ZI abundance $(n=100, r=-0.41$, $p<0.001)$, but no such correlation for more developed larvae in June 1999 or July 2000.

\section{Discussion}

\section{Lipid class contents}

Phospholipids were the dominant lipid class in all six pelagic development stages of larvae, accounting for 80 to $92 \%$ of the total lipid. This is 


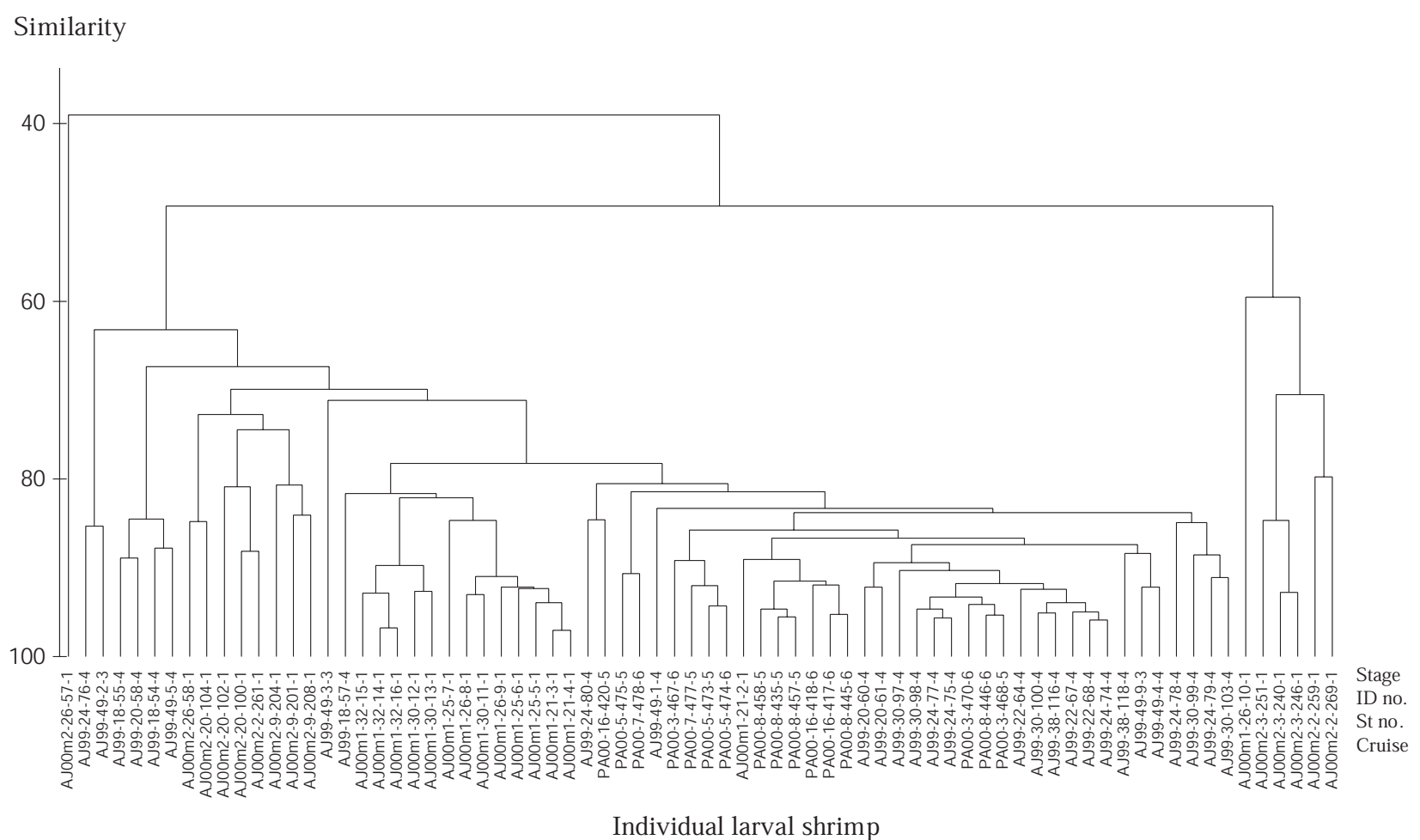

Fig. 4. Dendrogram of Bray-Curtis similarity indices of the fatty acid frequency compositions of individual shrimp larvae (no data transformation). The sample code is: Cruise-Station no.-Sample ID no.-Zoeal stage (1 = ZI, 3 = ZIII, 4 = ZIV, 5 = $\mathrm{ZV}, 6=\mathrm{ZVI})$. Hence, stage number is closest to $\mathrm{x}$-axis.

similar to findings in field collected $P$. borealis larvae (ZI and ZII) in Gulf of St. Lawrence (Ouellet et al., 1995) and adults from NE Greenland (Graeve et al., 1997), but higher than found for age 1+ in the north Norwegian Balsfjord (Hopkins et al., 1993). More surprising was the high contents of $\mathrm{HC}$, which has not previously been reported from lipid content studies of $P$. borealis larvae (Ouellet et al., 1992,1995) although reported for age 1+ (Hopkins et al., 1993). The decreasing trend of $\mathrm{HC}$ content with increasing larval size may reflect change in food and feeding. $\mathrm{HC}$ can consist of pristane (C19), C21:6, beta-carotene and others (Lee et al., 1971b; Gatten et al., 1979; Volkman et al., 1980; www.chiron.no). Pristane is a derivative of the phytol side chain of chlorophyll and $\mathrm{C} 21: 6$ is a major $\mathrm{HC}$ in phytoplankton as is betacarotene. HC in larval shrimp may therefore be an indication of phytoplankton feeding. The decreasing HC content with larval size could be an indication of reduced importance of phytoplankton in the diet. This is supported by food preference experiments performed by Rasmussen et al. (MS 2000) with P. borealis larvae on mixed diet. They found the larvae to feed on all food items, but the food selection seemed size dependent. Larvae in stage ZI and ZII had higher clearance rate for algae than for other items offered, while ZIII lost interest in planktonic algae (Rasmussen et al., MS 2000).

Larvae from June 1999 showed the highest FFA content, but also the highest TG, PL, and total lipid content (Table 1), indicating better lipid condition and higher feeding activity compared to larvae from July 2000. We suggest that the relatively high FFA content of the larvae from June 1999 was due to high feeding activity and anabolism (a model of lipid dynamics in Decapods is given on page 7 in Harrison (1990)). An investigation of a low number of shrimp larvae stomachs showed generally more stomach content in larvae from June than from July. This indicates that part of the elevated FFA content may originate from the stomach content. However, some FFA could also come from lipid degradation due to improper freezing storage, as noted in Results. Unlike in this study, Ouellet et al. (1995) found high content of DG and they suggested that in situations with low availability of FFA, the major flux from DG is directed in to PL synthesis. Our findings of relatively high FFA contents 
may suggest a direct relationship between food availability, contents of FFA and PL.

\section{Lipid condition and feeding}

Larval TG content correlate with physiological condition of a larva (Håkonson, 1984; Fraser, 1989; Ouellet et al., 1992, 1995; Harding and Fraser, 1999), and when exogenously derived energy exceeds the metabolic demand of a larva, the excess energy is accumulated as TG. We found a high proportion of larvae with low TG index $(<0.2)$ at stations with dense ZI concentrations in May and at nearly all stations in July for ZIV, ZV, and ZVI larvae indicating low food availability and feeding. According to Harding and Fraser (1999) a TG / ST ratio of 0.1 can be considered as the minimum survival threshold for lobster larvae to the next moult. For shrimp larvae in this study, the used minimum survival threshold of TG-index $=0.2$ equals a TG / ST ratio of $\sim 0.1$. The increasing trend of the ST $\mathrm{ww}^{-1}$ ratio of larvae above $\sim 2.5 \mathrm{~mm} \mathrm{cl}$ indicates a downward trend of TG / ST ratios with size relative to the TG-index used in this study. Laboratory studies found downward trends in TG / ST ratios due to starvation during development of shrimp and lobster larvae (Mourente et al., 1995; Harding and Fraser, 1999). The generally low lipid condition indices of the shrimp larvae from July 2000 (high proportion of TG-index <0.2) suggests low food availability and starvation (Fig. 2 and 3). P. borealis larvae have been suggested to settle during stage ZV (Astthorsson and Gislason 1991). In this study we caught both ZV and ZVI larvae, suggesting that these larvae were searching for food in the pelagic (Pedersen et al., 2002). A possible explanation could be that in years with food limitation larvae in low lipid condition stay in the pelagic in search for food. If the larvae do not reach a certain lipid condition level they may not settle and starve to death. The smaller $P$. montagui larvae were generally in better lipid condition than P. borealis (Fig. 3). This could indicate that the smaller larvae had an advantage over larger larvae at the time of sampling due to e.g. better food availability or less energy requirement.

Ouellet et al. (1995) suggested that the differences observed in the TG index among sampling sites reflect trophically induced variability which can be associated with different survival expectations at moult for ZI and ZII larvae. For crustaceans, a minimum storage of energy reserves during each development stage is critical for successful moulting and survival from one stage to the next (Ouellet et al., 1992; Harding and Fraser, 1999). We were unable to relate variable TG indices to within moult cycles. 22 larvae from July 2000 were identified as being close to moulting and their mean TG- and Lipcon indices were not significant different from the means of 178 larvae that were not close to moulting.

The fatty acid composition of shrimp larvae reflects to a certain extent, the food and feeding history of the larvae. The most recent feeding will be reflected in the fatty acid composition of recently ingested FFA and in neutral lipid reserves, mainly TG, while the fatty acid composition of PL reflect the food and feeding history over a longer feeding period. We were unable to find clear differences in the fatty acid composition of NL, FFA, and PL, which may indicate similar food composition over short and longer time periods. Neutral lipid reserves were generally found in low amounts, whereas phospholipids, mainly membrane fatty acids (20:5n-3, 22:6n-3, and 16:0), were far dominating. The latter supports the low dependence on lipid reserves. When larval food is in excess the surplus energy seems to be used for growth and/or stored as PL mainly.

\section{Lipid biomarkers, food web and lipid condition}

The use of fatty acids as biomarkers is based on studies of the lipid composition of marine phyto- and proto-plankton, which show that the fatty acid compositions are characteristic of the different taxa (Falk-Petersen et al., 1998; Reuss and Poulsen, 2002). Of the important phytoplankton in polar waters, the diatoms tend to be rich in 20:5(n-3), 16:1(n-7), and C16 PUFA but deficient in C18 PUFA, whereas the flagellates tend to be rich on $18: 4 n-3,18: 5 n-3$, and especially 22:6n-3 and deficient of 16:1(n-7) (FalkPetersen et al., 1998). The Haptophyceae Phaeocystis pouchetii that often dominate the blooms in polar waters are rich on C18 PUFA, especially $18: 4 n-3$ and $18: 5 n-3$, together with $20: 5 n-3$ and $22: 6 n-3$, while $16: 1 \mathrm{n}-7$ is found in very small amounts (Hamm et al., 2001). According to Falk-Petersen et al. (2000) oleic acid, 18:1n-9, is a major fatty acid of most marine animal lipids. 18:1n-7 is also frequently found in large quantities deriving from the elongation of $16: 1 \mathrm{n}-7$ that is likely to originate substantially from phytoplankton. This means that $16: 1 \mathrm{n}-7$ and $18: 1 \mathrm{n}-$ 7 in animal lipids tend to reflect phytoplanktonic dietary input, whereas $18: 1 \mathrm{n}-9$ reflects animal dietary input. The 20:1n-9 and 22:1n-11 units, present in very large amounts in calanoid copepods, are considered to be formed by de novo biosynthesis in these animals as the major site of the formation of 20:1n-9 and 22:1n-11 units in the marine food web 
(Falk-Petersen et al., 2000). Relating the above findings to the fatty acid compositions of the shrimp larvae in this study (Table 3), we find that larval $P$. borealis and P. montagui in development stage ZI to ZVI can be considered to be omnivorous. The fatty acid compositions of plankton $<300 \mu \mathrm{m}$ in May and June showed relatively high similarity with the fatty acid compositions of shrimp larvae. ZI larvae had lower $18: 1 \mathrm{n}-9 / \mathrm{n}-7$ ratio and ZIII to ZVI larvae had higher contents of $18: 1 n-9$ and 20:1n-9. Therefore, phytoplankton was a more important component in the diet of ZI larvae, whereas animal food became more important in the diet of ZIII to ZVI larvae.

Compared to $P$. borealis eggs and age $1+$ from Balsfjord (Hopkins et al., 1993), the larvae in this study contained higher amounts of PUFAn-3. PUFA, 20:5n-3 and 22:6n-3, cannot be synthesized de novo or in the required amount by most animals although essential for normal growth and survival (Bell and Sargent, 1996; St. John et al., 2001; Arts et al., 2001). In tiger prawn (Penaeus esculentus), Dall et al. (1992) found no clear evidence that 20:5n-3 and 22:6n-3 are essential and the essential 20:4n-6 could be synthesized from 18:2n-6. However, for larval shrimp (Crangon spp.) low amounts of PUFA may be interpreted as a consequence of unfavourable nutritional conditions (Kattner et al., 1994). ZI larvae from a coastal and a fjord station in May 2000 both had high larval abundance, low TG condition, lower proportions of $16: 0,16: 1 n-7,20: 5 n-3,22: 6 n-3$, and higher proportions of 18:0, compared to offshore collected ZI larvae. At these two stations, the fatty acid compositions of plankton $<300 \mu \mathrm{m}$ showed the same trend as in larval shrimp, indicating flagellate dominance at these two stations (Reuss and Poulsen, 2002). Therefore, poor food quality could be the reason for the observed low lipid condition of shrimp larvae at coastal and fjord stations in May 2000 (Fig.2).

The correlations between $16: 1 \mathrm{n}-7 / 16: 0$ ratios in larval shrimp and in plankton $<300 \mu \mathrm{m}$ for June and May, and the correlations between percentages of C18 fatty acids in larval shrimp and in plankton $<300 \mu \mathrm{m}$ for May, indicate that fatty acid biomarkers can be used as food web tracers in diatom dominated versus flagellate dominated water columns. Although elevated larval lipid condition indices at the westernmost station of $\operatorname{Tr} 3$, we were unable to find clear links between water regimes, plankton community structure (biomarkers), zooplankton concentrations, and larval shrimp condition indices. The low number of plankton and larval shrimp samples investigated with low resolution in time and space is probably the main reason for this. However, the links between the physical processes, plankton productivity and larval shrimp distribution over the West Greenland shelf are complex and strongly influenced by variability in climate (wind) and currents (Poulsen and Reuss, 2002; Pedersen et al., 2002). Reuss and Poulsen (2002) found fatty acids to be insufficiently specific to satisfactorily describe the composition of the plankton community. Fast changes in the physical-biological environment for the shrimp larvae due to turbulence will weaken the possibility of establishing clear links between larval shrimp lipid condition, food concentrations, and food web biomarkers.

\section{Conclusion}

Based on low lipid condition indices, we conclude that ZI larvae in high concentrations at coastal and fjord stations in May 2000 and most larvae from July 2000, were starving and had low probability of surviving the next moult. Lipid contents of larvae from June 1999 were more variable as were the physical environmental conditions, but generally the larvae were in higher lipid condition and more advanced in development compared to the larvae caught in July 2000 (Pedersen et al., 2002). This was most probably due to better feeding and growth history of the larvae caught in June 1999. Our results suggest variability in growth and survival expectations of $P$. borealis and $P$. montagui larvae related to variations in larval food availability between years. This is supported by the observation of a large 1999 and small 2000 year-class in the annual shrimp assessment survey. Hence, this study supports the hypothesis forwarded by Anderson (2000) that year-class strength variability of Pandalids mainly is determined during the pelagic larval phase by bottom-up processes and variability in the timing of zooplankton production.

\section{Acknowledgements}

Thanks to Greenland Institute of Natural Resources, the crews on R/V Adolf Jensen and R/V Paamiut. Special thanks to Claus C. Simonsen for excellent cooperation during the field program. Thanks also to the lipid laboratory at the Danish Institute for Fisheries Research (DIFRES) - Marlene Carlsen, Karin Bohn Jensen, Jack Melbye, and Inger Hornum for their effort with our lipid samples. Sigrun Jónasdóttir was helpful with the lipid separation methods. Special thanks to Benny Jensen (DIFRES) for help in the analysis of fatty acid contents, and the interpretations of the results. Especially, one of three 
anonymous reviewers gave helpful guidance for improvements of an earlier version of the manuscript. This work was based on economic support from the Danish Research Councils Committee on North Atlantic Research, Project no. 9803018.

\section{References}

ANDERSON, P. J. 2000. Pandalid Shrimp as Indicators of Ecosystem Regime Shift. J. Northw. Atl. Fish. Sci., 27: $1-10$.

ANGER, K. 1998. Pattern of growth and chemical composition in decapod crustacean larvae. Invert. Rep. Dev., 33: 2-3: 159-176.

ARTS, M. T., R. G. ACKMAN, and B. J. HOLUB. 2001. "Essential fatty acids" in aquatic ecosystems: a crucial link between diet and human health and evolution. Can. J. Fish. Aquat. Sci., 58: 122-137.

ASTTHORSSON, O. S., and A. GISLASON. 1991. Seasonal abundance and distribution of Caridea larvae in Ísafjorddeep, north-west Iceland. J. Plankton. Res., 13(1): 91-102.

BELL, M. V., and J. R. SARGENT. 1996. Lipid nutrition and fish recruitment. Mar. Ecol. Prog. Ser., 134: 315-316.

BUCH, E., M. H. NIELSEN, and S. A. PEDERSEN. 2002. On the coupling between Climate, Hydrography and Recruitment variability of Fishery Resources off West Greenland. Proceedings of the ICES Symposium on Hydrobiological variability in the ICES area, 1990-1999. ICES J. Mar. Sci., in press.

CHRISTENSEN, S., and N. VESTERGAARD. 1993. A bioeconomic analysis of the Greenland shrimp fishery in the Davis Strait. Mar. Res. Econ., 8: 345-365.

CLARKE, K. R., and R. M. WARWICK. 1994. Change in marine communities: an approach to statistical analysis and interpretation. Plymouth Marine Laboratory, Bourne Press Limited, Bournemouth, UK. 144 p.

CUSING, D. H. 1989. A difference in structure between ecosystems in strongly stratified waters and those that are only weakly stratified. J. Plankton. Res., 11: 1-13.

1995. Population production and regulation in the sea: A Fisheries perspective. Cambridge University Press. $354 \mathrm{p}$.

DALL, W., A. CHANDUMPAI, and D. M. SMITH. 1992. Fatty acid composition of organs and tissues of the tiger prawn Penaeus esculentus during the moulting cycle and during starvation. Mar. Biol., 113: 45-55.

DESVILETTES, CH, G. BOURDIER, C. H. AMBLARD, and B. BARTH. 1997. Use of fatty acids for the assessment of zooplankton grazing on bacteria, protozoans and microalgae. Freshwat. Biol., 38: 629-637. [1999 IN TEXT PAGE 2]

FALK-PETERSEN, S., J. R. SARGENT, J. HENDERSON, E. N. HEGSETH, H. HOP, and Y. B. OKOLODKOV. 1998. Lipids and fatty acids in ice algae and phytoplankton from the Marginal Ice Zone in the Barents Sea. Polar Biol., 20: 41-47.

FALK-PETERSEN, S., W. HAGEN, G. KATTNER, A. CLARKE, and J. R. SARGENT. 2000. Lipids, trophic relationships, and biodiversity in Arctic and Antarctic krill.
Can. J. Fish. Aquat. Sci., 57(Suppl.3): 178-191.

FRASER, A. J. 1989. Triacylglycerol content as a condition index for fish, bivalve, and crustacean larvae. Can. J. Fish. Aquat. Sci., 46: 1868-1873.

GATTEN, R. R., E. D. S. CORNER, C. C. KILVINGTON, and J. R. SARGENT. 1979. A seasonal survey of the lipids in Calanus helgolandicus Claus from the English Channel. In: Cyclic phenomena in marine plants and animals. Thirteenth European Marine Biology Symposium. E. Naylor and R.G. Hartnall (eds) Oxford: Pergamon Press, p. 275-284.

GRAEVE, M., G. KATTNER, and W. HAGEN. 1994a. Dietinduced changes in the fatty acid composition of Arctic herbivorous copepods: experimental evidence of trophic markers. J. Exp. Mar. Biol. Ecol., 182: 97-110.

GRAEVE, M., W. HAGEN, and G. KATTNER. 1994b. Herbivorous or omnivorous? On the significance of lipid compositions as trophic markers in Antarctic copepods. Deep Sea Res. (A), 42(5-6): 915-924.

GRAEVE, M., G. KATTNER, and D. PIPENBURG. 1997. Lipids in Arctic benthos: does the fatty acid and alcohol composition reflect feeding and trophic interactions? Polar Biol., 18: 53-61.

HAMM, C., M. REIGSTAD, C. W. RISER, A. MÜHLEBACH, and P. WASSMANN. 2001. On the throphic fate of Phaeocystis pouchetii. VII. Sterols and fatty acids reveal sedimentation of $P$. pouchetii-derived organic matter via krill fecal strings. Mar. Ecol. Prog. Ser., 209: 55-69.

HARDING, G. C., and A. J. FRASER 1999. Application of the triacylglycerol/sterol condition index to the interpretation of larval lobster Homarus americanus distribution in close proximity to Georges Bank, Gulf of Maine. Mar. Ecol. Prog. Ser., 186: 239-254.

HARRISON, K. E. 1990. The role of nutrition in maturation, reproduction and embryonic development of decapod crustaceans: A review. J. Shell. Res., 9(1): 1-28.

HOPKINS, C. C. E, J. R. SARGENT, and E. M. NILSSEN. 1993. Total lipid content, and lipid and fatty acid composition of the deep-water prawn Pandalus borealis from Balsfjord, northern-Norway: growth and feeding habits. Mar. Ecol. Prog. Ser., 96: 217-228.

HÅKONSON, J. L. 1984. The long and short term feeding condition in field-caught Calanus pacificus, as determined from lipid content. Limnol. Oceanogr., 29: 794-804.

KATTNER, G., I. S. WEHRTMANN, and T. MERCK. 1994. Interannual variations of lipids and fatty acids during development of Crangon spp. in the German Bight, North Sea. Comp. Biochem. Physiol, 107B(1): 103-110.

KHARLAMENKO, V. I., N. V. ZHUKOVA, S. V. KHOTIMCHENKO, V. I. SVETASHEV, and G. M. KAMENEV. 1995. Fatty acids as markers of food sources in a shallow-water hydrothermal ecosystem (Kraternaya Bight, Yankich Island, Kurile Islands). Mar. Ecol. Prog. Ser., 120: 231-241.

KIØRBOE, T. 2001. Food webs and fish production in the North Sea. Hist. Fil. Medd. Dan. Vid. Selsk., 82: 191210.

LEE, R. F., J. C. NEVENZEL, and G. A. PAFFENHÖFER. 
1971a. Importance of wax esters and other lipids in the marine food chain: phytoplankton and copepods. Mar. Biol., 9: 99-108.

LEE, R. F., J. HIROTA, and A. M. BARNETT. 1971 b. Distribution and importance of wax esters in marine copepods and other zooplankton. Deep Sea Res., 18: 1147-1165.

MOURENTE, G., A. MEDINA, S. GONZÁLEZ, and A. RODRÍGUEZ. 1995. Variations in lipid content and nutritional status during larval development of the marine shrimp Penaeus kerathurus. Aquaculture, 130: 87-199.

NIELSEN T. G., and B. W. HANSEN. 1995. Plankton community structure and carbon cycling on the western coast of Greenland during and after the sedimentation of a diatom bloom. Mar. Ecol. Prog. Ser., 125: 239-257.

OHMAN, M. D. 1996. Freezing and storage of copepod samples for the analysis of lipids. Mar. Ecol. Prog. Ser., 130: 295-298.

OUELLET, P., LEFAIVRE, D., and V. KOUTITONSKY. 1990. Distribution of shrimp (Pandalus borealis) larvae and hydrographic pattern in the northern Gulf of St. Lawrence. Can. J. Fish. Aquat. Sci., 47: 2068-2078.

OUELLET, P., TAGGART, C. T., and K. T. FRANK. 1992. Lipid condition and survival in shrimp (Pandalus borealis) larvae. Can. J. Fish. Aquat. Sci., 49: 368-378.

OUELLET, P., TAGGART, C. T., and K. T. FRANK. 1995. Early growth, lipid composition, and survival expectations of shrimp Pandalus borealis larvae in the northern Gulf of St. Lawrence. Mar. Ecol. Prog. Ser., 126: 163-175.

PARRISH, C. C. 1987. Separation of aquatic lipid classes by chromarod thin-layer chromatography with measurement by iatroscan flame ionisation detection. Can. J. Fish. Aquat. Sci., 44: 722-731.

PARRISH, C. C., T. A. ABRAJANO, S. M. BUDGE, R. J. HELLEUR, E. D. HUDSON, K. PULCHAN, and C. RAMOS. 2000. Lipid and phenolic biomarkers in marine ecosystems: Analysis and applications. The Handbook of Environmental Chemistry Vol. 5 Part D Marine Chemistry, (P. Wangersky (ed.), Springer-Verlag Berlin Heidelberg, p. 193-223.

PEDERSEN L., H. M. JENSEN, A. BURMEISTER, and B. W. HANSEN. 1999. The significance of food web structure for the condition and tracer lipid content of juvenile snail fish (Pisces: Liparis spp.) along $65^{\circ}-72^{\circ} \mathrm{N}$ off West Greenland. J. Plankton. Res., 21: 1593-1611.

PEDERSEN, S. A., AND J. RICE. 2002. Dynamics of fish larvae, zooplankton, and hydrographical characteristics in the West Greenland Large Marine Ecosystem 19501984. In: Large Marine Ecosystems of the North Atlantic. Changing States and Sustainability. K. S. Shermann, and H.-R. Skjoldal (eds.). Chapter 5. Elsevier Science (www.elsevier.com/locate/isbn/0444510117).

PEDERSEN, S. A., C. S. SIMONSEN, and L. STORM. 2002. Northern shrimp (Pandalus borealis) recruitment in West Greenland waters. Part I. Distribution of Pandalus shrimp larvae in relation to hydrography and plankton. J. Northw.
Atl. Fish. Sci., 30: 19-46 (this issue).

POULSEN, L. K., and N. REUSS. 2002. The plankton community on Sukkertop and Fylla Banks off West Greenland in a spring bloom and post-bloom period. Hydrography, phytoplankton and protozooplankton. Ophelia, 56(2): 69-85.

RASMUSSEN, T., M. ASCHAN, and J. S. CHRISTIANSEN. MS 2000. The implementation of laboratory studies to recruitment modelling - a brief review of experimental procedures. ICES C.M. Doc., No. R:07, 16 p.

REFSGAARD, H. H. F., P. M. B. BROCKHOFF, and B. JENSEN. 2000. Free Polyunsaturated Fatty Acids Cause Taste Deterioration of Salmon during Frozen Storage. J. Agric. Food. Chem., 48: 3280-3285.

REUSS, N., and L. K. POULSEN. 2002. Evaluation of fatty acids as biomarkers for a natural plankton community. A field study of a spring bloom and a post-bloom period off West Greenland. Mar. Biol., 141: 423-434. Published online.

SARGENT, J. R., and K. J. Whittle. 1981. Lipids and hydrocarbons in the marine food web. In: Analysis of marine ecosystems. A. R. Longhurst (ed.), Academic Press, London, p. 491-533.

SARGENT, J. R., R. J. PARKES, I. MUELLER-HARVEY, and R. J. HENDERSON. 1987. Lipid biomarkers in marine ecology. M. A. Sleigh (ed.), Microbes in the sea. Chichester, Ellis Horwood., p. 119-138 (Ch. 5).

SARGENT, J. R., and S. FALK-PETERSEN. 1988. The lipid biochemistry of calanoid copepods. Hydrobiologia, 167168: $101-114$.

SAS. 1985. SAS User's Guide: Basics/Statistics Version 5. SAS Institute Inc., Raleigh, North Carolina.

STICKNEY, A. P., and H. C. PERKINS. 1981. Observations on the food of the larvae of the northern shrimp, Pandalus borealis Kröyer (Decapoda, Caridea). Crustaceana, 40(1): 36-49.

ST. JOHN, M. A., and T. LUND. 1996. Lipid biomarkers: linking the utilization of frontal plankton biomass to enhanced condition of juvenile North Sea cod. Mar. Ecol. Prog. Ser., 131: 75-85.

ST. JOHN, M. A., C. CLEMMESEN, T. LUND, and T. KÖSTER. 2001. Diatom production in the marine environment: implications for larval fish growth and condition. ICES J. Mar. Sci., 58: 1106-1113.

STRIBY, L., R. LAFONT, and M. GOUTX. 1999. Improvement in the Iatroscan thin-layer chromatographicflame ionisation detection analysis of marine lipids. Separation and quantification of monoacylglycerols and diacylglycerols in standards and natural samples. J. Chromatogr., A 849: 371-380.

VOLKMAN, J. K., R. R. GATTEN, and J. R. SARGENT. 1980. Composition and origin of milky water in the North Sea. J. Mar. Biol. Ass. U.K., 60:759-768.

WHYTE J. N. C. 1988. Fatty acid profiles from direct methanolysis of lipids in tissue of cultured species. Aquaculture, 75: 193-203. 
Appendix 1: Figure showing lipid composition of Pandalus sp. larvae.
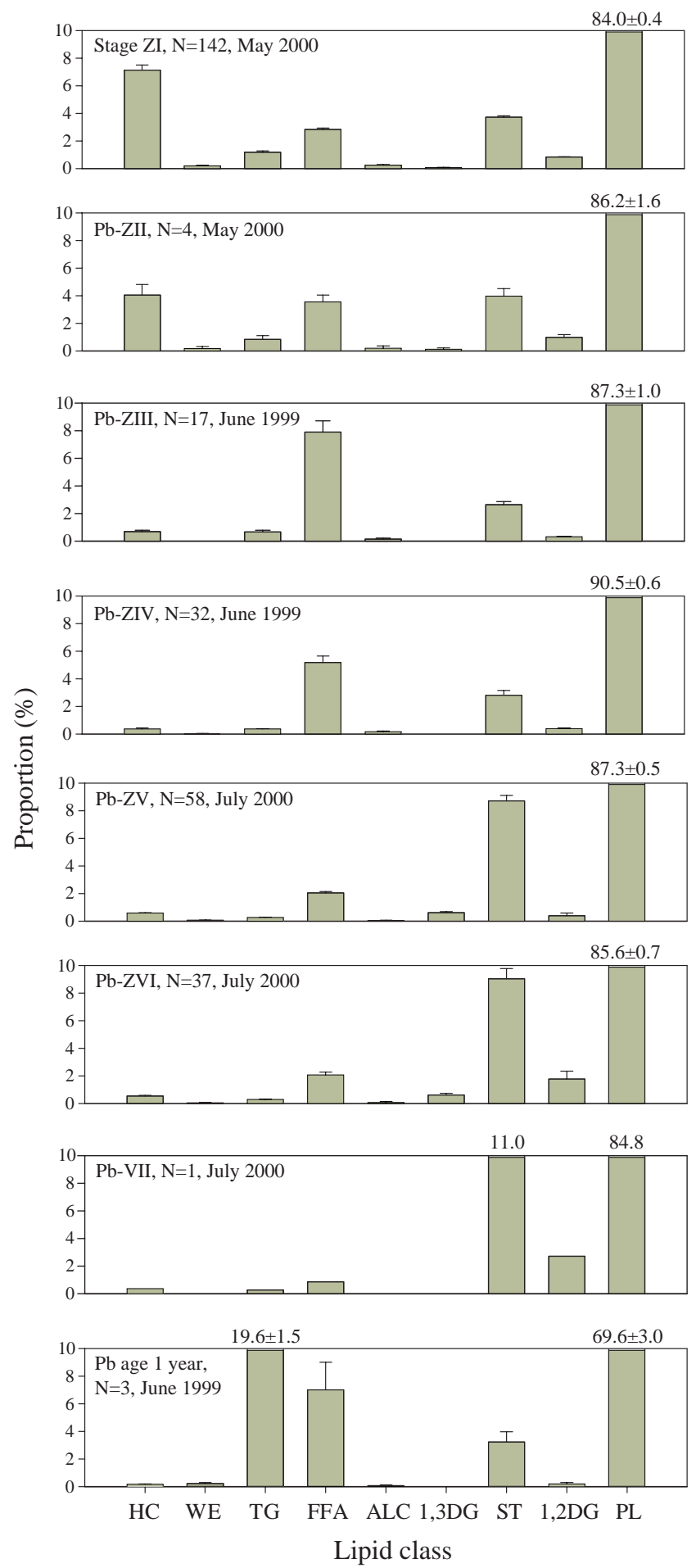

Fig. 1. Percent lipid composition of $P$. borealis $(\mathrm{Pb})$ larval stages ZI to ZVI, VII, and 1 year old. Stage ZI includes also P. montagui larvae. Mean of $\mathrm{N}$ individuals, standard error indicated on columns. $\mathrm{HC}=$ hydrocarbons, $\mathrm{WE}=$ wax esters, $\mathrm{TG}=$ triacylglycerols, $\mathrm{FFA}=$ free fatty acids, $\mathrm{ALC}=$ alcohols, $1,3 \mathrm{DG}=1,3$ diacylglycerol, $\mathrm{ST}=$ free sterols, $1,2 \mathrm{DG}=1,2$ diacylglycerol, $\mathrm{PL}=$ phospholipids . 